\title{
DO FREE TRADE REGIMES AND COMMON CURRENCY DRIVE EXPORT GROWTH?
}

\section{Mindaugas Butkus, Henrikas Karpavičius, Kristina Matuzevičiūtė*}

\begin{abstract}
It is believed that in many countries export activities could enhance countries' capabilities. It is also believed that trade liberalization or common currency could be an export driver. This paper examines the impact of trade liberalization and common currency on EU countries' export growth. The methodology applied in this research is constructed using specifics of the data that arise from a natural experiment. We examined how exogenous events like joining the EU, WTO, EFTA or becoming a member of Eurozone change the environment, in which countries trade. The results using an unbalanced panel data consisting of $28 \mathrm{EU}$ countries for the period 1995-2015 revealed that membership in WTO instantly increases export by $12.5-13.5 \%$, but has no extra effect in longer period; membership in the EU and EFTA has effect on export with a time lag and common currency did not affect export growth at all.
\end{abstract}

Keywords: export growth, trade regimes, common currency

JEL Classification: F13, F40, F42

\section{Introduction}

It is agreed that economic development of a country can be characterized by an intense integration of economies when business is looking for new markets to trade around the world, at the same time rapidly increasing country's export volumes. Export is the shortest and most effective way of integration into global market, the majority of existing international trading regimes have expanded and the new ones have been established over the last few decades. The relationship between trade liberalization, common currency and export growth has become very important, especially in the EU. Despite an increasing interest there has been limited research made in this field quantifying these benefits.

Many research activities assessing an impact of trade liberalisation and common currency on export growth are based on the orthodox supply tradition. Some researchers confirm that countries after changing trade regimes improved their export performance (SantosPaulino, 2007; Ju et al., 2010; Kassim, 2015; Zakaria, 2014). On the other hand, other researchers have found little evidence to confirm this relationship (Ratnaike, 2012; Allaro, 2012; Mukherjee and Chanda, 2017). The review of the literature on this topic revealed

* Mindaugas Butkus, Social Innovation Research Centre of Šiauliai University Research Institute, Lithuania (mindaugas.butkus@su.lt);

Henrikas Karpavičius, Department of Economics of Šiauliai University, Lithuania (henrikas. karpavicius@su.lt);

Kristina Matuzevičiūtė, Social Innovation Research Centre of Šiauliai University Research Institute, Lithuania (kristina.matuzeviciute@su.lt). 
that supply-side models do not provide clear evidence of the relationship between trade regimes, common currency and export flows. The contradiction of the predictions reinforces the importance of investigating this relationship using alternative empirical methodology.

Considering the above mentioned, in this paper we aim to examine an impact of trade liberalisation and common currency on export growth in the EU countries applying export demand-side model.

The rest of the research is organised as follows: Section 2 presents theoretical background of the economic and monetary integration and literature review of export determinants. The background of the model and variables in use are explained in Section 3. Section 4 presents the results of empirical analysis and discussion. Section 5 closes the paper with conclusions.

\section{Literature Review on Economic and Monetary Integration and Determinants of Export}

Traditional explanation of export driving determinants was based on comparative advantage theory developed by Ricardo (1955), Heckscher and Ohlin (1991), Samuelson (1975), Vanek and Bertrand (1971). According to this approach, countries trade because they have different terms of technology or relative supply of production factors that influence different productivity levels. The weakness of this approach is that it ignores the fact that trade barriers affect the export variety and growth. Francois et al. (2004) and Winters (2004) emphasize welfare and trade gains of participation in creating free trade agreements (FTAs). Performance of export is strongly determined by access to foreign markets. Improving market access requires removing trade barriers. This can be achieved by FTA which removes trade restrictions between the countries. However, improved market access through negotiations of FTAs at WTO or the EU is not a sufficient condition for actual export growth. Shujiro (2002) noted that the effects of trade regimes on export can be classified into static and dynamic effects. Static effects include: (i) the trade creation effect when trade is created between the countries by removing the trade restrictions within the group; (ii) the trade diversion effect which redirects import from more efficient non-members towards less efficient members; (iii) the terms of trade effect influence the improved trade conditions between members due to the greater flows of trade between member states and their increased influence on non-member countries. Dynamic effects which include: (i) the market expansion effect which is achieved through economies of scale and the access to better venues for production and distribution as trade restrictions are removed and the market expands; (ii) the competition enhancement effect through facilitating efficient production because market integration influences grater competitiveness of the oligopolistic companies in the region.

Analysing the effects of monetary unions on export performance authors find contradictory results. Early researches find that adopting a single currency positively affects the trade volumes. Dell'Ariccia (1999) concludes that there is a negative relation between exchange rates and export. Rose and van Wincoop (2001) revealed large and significant effect of single currency on trade. This suggests that, as stated in the IMF (2003) research, the benefits for export growth of currency unions exceed reduction of exchange rate volatility. 
Table 1 | The Proposed Determinants by Scientific Literature

\begin{tabular}{|c|c|c|c|c|c|c|}
\hline \multicolumn{2}{|c|}{$\begin{array}{l}\text { Determi- } \\
\text { nant }\end{array}$} & Research / period analysed & $\begin{array}{l}\text { Positive } \\
\text { Signifi- } \\
\text { cant }\end{array}$ & $\begin{array}{l}\text { Not } \\
\text { Signifi- } \\
\text { cant }\end{array}$ & $\begin{array}{l}\text { Negative } \\
\text { Signifi- } \\
\text { cant }\end{array}$ & Methods \\
\hline \multirow{5}{*}{ 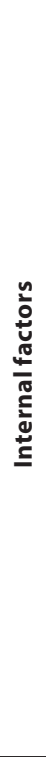 } & \multirow[t]{2}{*}{ 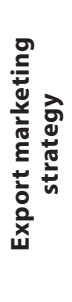 } & $\begin{array}{l}\text { Eusebio et al. (2007) / ND } \\
\text { Mavrogiannis et al. (2008) / 1999-2001 } \\
\text { Tantong et al. (2010) / 2001 } \\
\text { Lages et al. (2009) / 1999 } \\
\text { Gaur and Gupta (2011) / } 2001 \text { and } 2008 \\
\text { Carneiro et al. (2011) / } 2006 \\
\text { Williams (2012) / ND }\end{array}$ & $\mathrm{X}$ & & & $\begin{array}{l}\text { (I)SEM with } \\
\text { OLS and WLS } \\
\text { estimations; } \\
\text { Analysis } \\
\text { of covariance }\end{array}$ \\
\hline & & Adis, (2010) / ND & & $\mathrm{X}$ & & $\begin{array}{l}\text { Multiple } \\
\text { regression }\end{array}$ \\
\hline & 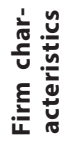 & $\begin{array}{l}\text { Brouthers and Nakos (2005) / ND } \\
\text { D'Angelo (2012) / } 2003 \\
\text { Calabro, Mussolino (2013) / 2003-2006 } \\
\text { Reis, Forte (2014) / 2008-2010 } \\
\text { Akdeve (2013) / ND }\end{array}$ & $\mathrm{X}$ & & & $\begin{array}{l}\text { Regression } \\
\text { models } \\
\text { (hierarchical, } \\
\text { Tobit, multiple } \\
\text { linear) }\end{array}$ \\
\hline & \multirow{2}{*}{ 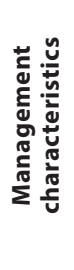 } & Lages and Montgomery (2005) / 1999 & & $\mathrm{X}$ & & $\begin{array}{l}\text { SEM with WLS } \\
\text { estimation }\end{array}$ \\
\hline & & $\begin{array}{l}\text { Brouthers and Nakos (2005) / ND } \\
\text { Ottaviano and Martincus (2011) / } \\
1996-1998 \\
\text { Stoian et al. (2011) / } 2008 \\
\text { Hultman et al. (2011) / ND } \\
\text { Adu-Gyamfi and Korneliussen (2013) / ND }\end{array}$ & $\mathrm{X}$ & & & $\begin{array}{l}\text { Regression } \\
\text { models } \\
\text { (hierarchical, } \\
\text { GMM, multiple } \\
\text { linear) } \\
\text { Path analysis }\end{array}$ \\
\hline \multirow{6}{*}{ 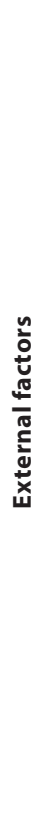 } & \multirow{3}{*}{ 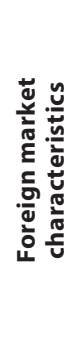 } & Baldauf et al. (2000) / 1991-1995 & & $\mathrm{X}$ & & $\begin{array}{l}\text { Descriptive } \\
\text { statistics }\end{array}$ \\
\hline & & $\begin{array}{l}\text { O'Cass and Julian (2003) / ND } \\
\text { Lee and Griffith (2004) / ND } \\
\text { Singh (2009) / 1990-2005 }\end{array}$ & $\mathrm{X}$ & & & $\begin{array}{l}\text { Multiple re- } \\
\text { gression with } \\
\text { OLS and PLS } \\
\text { estimation }\end{array}$ \\
\hline & & $\begin{array}{l}\text { Balabanis and Katsikea (2003) / ND } \\
\text { lyer (2010) / 2000-2006 }\end{array}$ & & & $\mathrm{X}$ & $\begin{array}{l}\text { Multiple re- } \\
\text { gression with } \\
\text { OLS and RE } \\
\text { estimation }\end{array}$ \\
\hline & \multirow{3}{*}{ 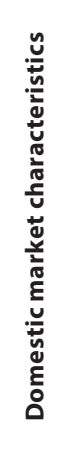 } & $\begin{array}{l}\text { Alvarez (2004) / } 2001 \\
\text { Lages and Montgomery (2005) / } 1999 \\
\text { Reis and Forte (2014) / ND } \\
\text { Williams (2012) / 2008-2010 } \\
\text { Stoian et al. (2011) / 2008 } \\
\text { Ottaviano and Martincus (2011) / } \\
\text { 1996-1998 }\end{array}$ & $x$ & & & $\begin{array}{l}\text { SEM with WLS } \\
\text { estimation } \\
\text { Regression } \\
\text { models (Logit, } \\
\text { multiple linear, } \\
\text { GMM) }\end{array}$ \\
\hline & & $\begin{array}{l}\text { Baldauf et al. (2000) / 1991-1995 } \\
\text { Carrere et al. (2006) / 1962-1996 } \\
\text { Gao et al. (2010) / 2001-2005 }\end{array}$ & & $\mathrm{X}$ & & $\begin{array}{l}\text { Multiple } \\
\text { regression }\end{array}$ \\
\hline & & $\begin{array}{l}\text { lyer (2010) / 2000-2006 } \\
\text { Guner et al. (2010) / 2001-2005 }\end{array}$ & & & $\mathrm{X}$ & $\begin{array}{l}\text { Multiple re- } \\
\text { gression with } \\
\text { OLS and RE } \\
\text { estimation }\end{array}$ \\
\hline
\end{tabular}

Note: ND - no data.

Source: Authors' analysis based on scientific literature presented in Table 1. 
Frankel (2008) states that euro as a single currency has effect on intra-trade volume not only for short but also for long term. The author also considered that Euro is still very young currency so the effect is less than earlier researches found. Murphy and Siedschlag (2011) estimated that monetary integration had positive, significant and increasing effect on export. Bouchoucha (2015) analysis showed that the real effective exchange rate has bigger impact on exports between euro area countries than on global exports.

Recent research (Sousa et al., 2008; Maurel, 2009; Carole, 2009; Katsikeas et al., 2010; Moghaddam et al., 2011; Stioan et al., 2011) reveals that export driving determinants can be divided into two groups: internal and external. Internal factors include firm-specific elements: the company size, the company's international experience, and the company's capabilities and competencies (e.g. resource extent, relationship with customer, product exclusivity, product quality, and flexibility to react to market changes). External factors include foreign market characteristics, such as cultural similarity, economic growth of trade partners, governmental regulations or membership in trade agreements, market competitiveness, and exchange rate and its volatility, etc., that influence export performance, as well as domestic market characteristics. Table 1 shows the categorization of determinants by scientific literature.

The external determinants are classified as domestic and foreign country characteristics. These characteristics are mainly influenced by industry and market specific. Export performance is determined by legal, economic and cultural differences. Also, it can be stated that there are (1) supply-side determinants: (i) production capacity (resources, productivity, climate, stocks, projected profitability, world export rates, exchange rate); (ii) alternative use in domestic market; and (2) demand-side determinants: (i) foreign demand (market size, foreign income, population, preferences, world export prices, exchange rate); (ii) trade restriction (tariff and non-tariff barriers, regulatory barriers); (iii) competitiveness (production and transportation costs, productivity, exchange rate).

The scientific literature analysis revealed that (i) research is fragmented, including a variety of methodological approaches, but mainly based on supply-side models, (ii) diverse, analysing a vast number of different factors influencing export growth, and (iii) ambiguous, reporting inconclusive results about the impact on export growth, (iv) mostly bilateral trade flows are analysed not paying attention to multilateral trade agreements.

\section{Data and Model}

To explore empirically membership impact on export growth, we use an unbalanced panel (cross-country, time series) data covering 28 EU member states over the period 1995-2015. The main data is collected from Eurostat and data on export partners' economic growth from WDI database. For over 40 years, the gravity model has been the main instrument to analyse the flows of international trade and the impact of trade agreements on export performance at cross-country level. The disadvantage of gravity model is that it explains only countries' bilateral trade flows. So we developed a demand-side model which is capable to capture the effect of membership on countries' multilateral trade flows. 
The methodology applied in this research is constructed taking into account specifics of the data that arise from a natural experiment (or a quasi-experiment) which takes place when an externally determined event - for example a change in policy course - changes the conditions in which countries trade. Differently, compared to a true experiment, when treatment and control groups are assigned randomly, independently and clearly, in natural experiments the control and treatment groups arise due to the change in government's policy. And because of that, seeking to account for systematic differences between the two, we need data of at least two years, one before the policy intervene and one after that, as well as array of control variables.

In the simplest membership-effect evaluation model, a sample of countries is obtained in the first time period. Some of these countries then join a particular trade regime in a later time period and form the treatment group; countries, that do not join a particular trade regime, form the control group. The equation of interest that has unobserved effect form is:

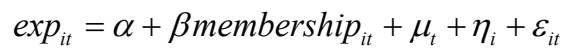

where membership $p_{i t}$ is a dummy variable that indicates whether the country $i$ belongs to a particular trade regime in year $t$ or not; $\exp _{i t}$ is the logarithm of export at constant prices; $\mu_{t}$ is a time specific effect; $\eta_{i}$ is an unobserved country-specific fixed effect; and $\varepsilon_{i t}$ is the error term. If membership only occurred in the later period, then the OLS estimator of $\beta$ has a very simple difference-in-differences representation:

$$
\hat{\beta}=\overline{\operatorname{sexp}}_{\text {treat }}-\overline{\Delta \exp }_{\text {control }}
$$

When additional explanatory variables are added to Equation 1 to control the fact that the export environment in sampled countries may differ systematically over analysed periods, the OLS estimate of $\beta$ no longer has the simple form of Equation 2, but its interpretation remains similar. That is, we calculate the average change in $\exp$ over two years for the treatment, as well as for control groups and $\hat{\beta}$ is the difference between these changes. If membership takes place in both periods (as it is in our case for some of the countries), $\hat{\beta}$ cannot be written as in Equation 2, but we interpret it in the same way: it is the change in the average value of $\exp$ due to membership.

Model suitable for empirical estimation taking into account covered trade regimes and control variables, which we will employ in our analysis, is:

$$
\exp _{i t}=\alpha+\beta_{1} e u_{i t}+\beta_{2} m u_{i t}+\beta_{3} w t o_{i t}+\beta_{4} e f t a_{i t}+c_{1} g d p_{i t}+c_{1} \text { volat }_{i t}+\mu_{t}+\eta_{i}+\varepsilon_{i t}
$$

where $e u_{i t}, m u_{i t}, w t o_{i t}$ and $e f t a_{i t}$ are dummy variables indicating whether the country belongs to European Union, Monetary Union, World Trade Organization or European Free Trade Agreement, respectively; $g d p_{i t}$ and volat $_{i t}$ are control variables denoting GDP of export partners ${ }^{1}$

We used weighted average of log GDP at constant prices of ten main trade partners, weights were assigned according to trade shares. 
and country exchange rate volatility, ${ }^{2}$ respectively, that accounts for main determinants of export demand. We are interested here in testing whether the marginal impact of joining the European Union, the Monetary Union, the World Trade Organization or the European Free Trade Agreement on export, $\beta_{1}, \beta_{2}, \beta_{3}, \beta_{4}$, respectively, is statistically significant.

In Equation 3 we use logs of variables to shape relationships in linear form, but here we do not address issues regarding endogeneity. Theoretically, however, it is plausible, and also very likely, that leftover country specific effects (that were not captured by our model) are correlated with right-hand side variables of the model. And because these effects will not be estimated, they will account for a part of variation in error term what would probably lead to a partial correlation between error term and dependent variable of the model. This would further lead to inconsistently estimated effects of independent variables on export. We assume that unobserved effects that influence outcome variable appear in two types: time-invariant variables and those varying over time. The variable $\eta_{i}$ covers all unobserved, time-invariant independent variables that affect $\exp _{i t}$. Because of that we can name Equation 3 as the unobserved effects model. Hence, by differencing variables in this equation we can control the unobserved effects and solve endogeneity problem. Taking into account the above mentioned, we obtain:

$$
\exp _{i t}-\exp _{i t-1}=\beta\left(X_{i t}-X_{i t-1}\right)+c\left(C O N_{i t}-C O N_{i t-1}\right)+\left(\varepsilon_{i t}-\varepsilon_{i t-1}\right)
$$

where $X_{i t}$ is now the set of dummy variables including European Union, Monetary Union, World Trade Organization and European Free Trade Agreement. CON $N_{i t}$ is the set of control variables presented in the Equation 3 including time specific effects. The unobserved effect, $\eta_{i}$, does not appear in Equation 4: it has been "differenced away". We should note here that differences of logged variables approximate growth rates, thus Equation 4 is suitable for estimating membership, as well as exchange rate volatility and trade partners' economic growth impact on export growth. Equation 4 has another advantage $-\beta$ mirrors the difference-in-differences estimator. In our case, $\beta$ is the change in the average value of $\exp$ due to membership. After differencing and taking into account the period covered by the analysis, model takes a form of:

$$
\begin{aligned}
& \Delta \exp _{i t}=\alpha+\mu_{1997}+\ldots+\mu_{2015}+\beta_{1} \Delta e u_{i t}+\beta_{2} \Delta m u_{i t}+\beta_{3} \Delta w \text { to }_{i t}+\beta_{4} \Delta e f t a_{i t} \\
& +c_{1} \Delta g d p_{i t}+c_{1} \Delta \text { volat }_{i t}+\varepsilon_{i t}
\end{aligned}
$$

To ensure validity of commonly used standard errors and test statistics, we need to assume that error is not correlated over time. This can be tested using $\operatorname{AR}(1)$ model with $\Delta \varepsilon_{i t}$ - in case when error follows a stable model, then $\Delta \varepsilon_{i, t}$ will be serially correlated, if error is randomly distributed, $\Delta \varepsilon_{i, t}$ will be not correlated over time. When residuals do not exhibit correlation over time, we can address commonly used methods to deal with heteroscedasti-city, i.e. White test, as well as to compute robust estimators. In panel data (with time-series and a cross-sectional dimensions) analysis we aim to use robust estimation of the covariance matrix that would adjust both -

2 We calculated log of standard deviation of monthly Real Effective Exchange Rate estimated using 42 trading partners. 
heteroscedasticity and autocorrelation and because of that we will use HAC (heteroscedasticity and autocorrelation consistent) approach that is proposed by Arellano (2003) for the panel data. Absence of endogeneity in the model will be tested using augmented regression Durbin$\mathrm{Wu}-$ Hausman (DWH) test explained by Davidson and MacKinnon (1993).

\section{Estimation Results}

This section presents estimates of the parameters in Equation 5. We will start discussing our research results with the estimated parameters presented in Table 2 Column 1. Estimation results show that joining the EU, becoming member of EFTA or part of Eurozone did not affect export growth instantly. On the other hand, becoming a member of WTO has a huge impetus for export growth. As our estimation results show, membership in WTO accounts for additional $12.5-13.5 \%$ growth of export. This estimation explains just instant effect of membership, i.e. for the first year as a member.

Table 2 | Estimation Results of Membership Impact on Export

\begin{tabular}{|c|c|c|c|}
\hline & (1) & (2) & (3) \\
\hline Constant & $0.046^{* *}$ & $0.096^{* *}$ & $0.059^{* *}$ \\
\hline Volatility of Real Effective Exchange Rate & $-0.013^{* *}$ & $-0.013^{* * *}$ & $-0.013^{* * *}$ \\
\hline Economic Growth of Main Trade Partners & $0.584^{* *}$ & $0.571^{* * *}$ & $0.555^{* * *}$ \\
\hline \multicolumn{4}{|l|}{ Membership in: } \\
\hline EU & $0.062^{*}$ & $0.061^{*}$ & 0.033 \\
\hline$(-1)$ & - & $0.059 * *$ & $0.063^{* *}$ \\
\hline$(-2)$ & - & - & $0.058^{* *}$ \\
\hline MU & 0.007 & 0.008 & 0.008 \\
\hline$(-1)$ & - & 0.032 & 0.032 \\
\hline$(-2)$ & - & - & -0.012 \\
\hline WTO & $0.125^{* *}$ & $0.133^{* *}$ & $0.131^{* *}$ \\
\hline$(-1)$ & - & 0.014 & 0.014 \\
\hline$(-2)$ & - & - & 0.034 \\
\hline EFTA & 0.010 & 0.012 & -0.023 \\
\hline$(t-1)$ & - & $0.051^{* *}$ & $0.052^{* *}$ \\
\hline$(t-2)$ & - & - & 0.001 \\
\hline $\mathbf{n}$ & 492 & 478 & 464 \\
\hline Adj. $R^{2}$ & 0.5392 & 0.5524 & 0.5555 \\
\hline$p$-value of DWH test & 0.1056 & 0.1103 & 0.0984 \\
\hline
\end{tabular}

Note: Robust (HAC) standard errors are used. All regressions include time dummies. ${ }^{*}$ indicates significance at the $10 \%$ level; ${ }^{* *}$ indicates significance at the $5 \%$ level; ${ }^{* * *}$ indicates significance at the $1 \%$ level. Source: Authors' calculations. 
Estimation results presented in Columns 2 and 3 can shed some light on this effect with a lag in time. Adding lags of membership variables for one year (in Column 2) and for two years (in Column 3) does not revealed an effect of becoming Eurozone member on export. In the frames of our model we do not see evidence to support one of the main arguments to join the Monetary Union - abatement of international trade and thus inducing export growth. Membership in WTO after a year or two has no additional effect to that what we have seen in the current period. Joining the EU accounts for additional export growth with a lag $-5.9 \%$ after a year and $12.1 \%$ after two years and EFTA for 5.1\% after a year. In consistence with earlier researches on export growth, we also find that increasing exchange rate volatility negatively affects export and economic growth in trade partners' countries has positive effect.

Further, we estimated the same Equation 5 separately for export of goods and services. Estimation results are presented in Table 3. As we compare estimation results presented in Table 2 Column 1 with those in Table 3 Columns 1 and 4, it becomes clear that results deviate just in impact magnitude. Membership in WTO had a way bigger impact on export of goods compared with export of services. Joining WTO accounts for additional $17 \%$ growth in export of goods and for 5\% in case of export of services. As we have already mentioned, impact of becoming a member of WTO occurs instantly and does not facilitate additional growth after few years. On the contrary, membership in the EU has a slightly bigger impact on export of services compared with export of goods. Estimation results show that in both cases impact occurs with a time lag - in case of export of services $13.3 \%$ and in case of export of goods $8.5 \%$ after two years. Estimation results show that EFTA affects just export of goods but not export of services. As in case of total export, membership in Eurozone has no effect.

Estimation parameters of control variables reveal some interesting insights about how sensitive export of goods and of services are to the main factors. We can see that export of goods is about 3.5 times more sensitive to volatility of exchange rate compared with export of services. We also see that export of goods is relatively inelastic in respect of economic growth $-10 \%$ economic growth in trade partner countries leads to increase of export by $2.3 \%$. Export of services is much more sensitive to economic fluctuations. Estimated coefficient of elasticity is about 1.1 .

Our research revealed a huge role within the framework of regulation of the global trade relations that was played by WTO aiming to free the international trade from various political, economic and legal restrictions applied at a national level. This finding is in line with Santos-Paulino (2007) and Ju et al. (2010) who confirmed that countries after entering WTO improved their export performance. The complexity inherent in WTO trade regimes is reflected in Doha Development Agenda (DDA) that has been ongoing since 2001. Critical voices are now calling for an abandonment of existing decision-making mechanisms of the DDA. If global trade is to drive development and prosperity in this century as strongly as it did in the previous, there is a need for WTO that reflects today's economic realities and it is time for the world to free itself of the strictures of Doha. 
Table 3 | Estimation Results of Membership Impact on Export of Goods and Services

\begin{tabular}{|c|c|c|c|c|c|c|}
\hline & \multicolumn{3}{|c|}{$\begin{array}{l}\text { Dependent variable - } \\
\text { export of goods }\end{array}$} & \multicolumn{3}{|c|}{$\begin{array}{l}\text { Dependent variable - } \\
\text { export of services }\end{array}$} \\
\hline & (1) & (2) & (3) & (4) & (5) & (6) \\
\hline Constant & $0.052^{* *}$ & $0.100^{* *}$ & $0.059^{* *}$ & $0.030^{*}$ & $0.082^{* *}$ & $0.058^{* *}$ \\
\hline $\begin{array}{l}\text { Volatility of Real } \\
\text { Effective Exchange } \\
\text { Rate }\end{array}$ & $-0.023^{* * *}$ & $-0.027^{* * *}$ & $-0.025^{* * *}$ & $-0.007^{* * *}$ & $-0.007^{* *}$ & $-0.007^{* *}$ \\
\hline $\begin{array}{l}\text { Economic Growth } \\
\text { of Main Trade } \\
\text { Partners }\end{array}$ & $0.216^{* * *}$ & $0.248^{* * *}$ & $0.234^{* * *}$ & $1.070^{* *}$ & $1.052^{* *}$ & $1.066^{* *}$ \\
\hline \multicolumn{7}{|l|}{ Membership in: } \\
\hline EU & 0.027 & 0.026 & 0.026 & 0.040 & 0.040 & 0.041 \\
\hline$(-1)$ & - & $0.046^{* *}$ & $0.046^{* *}$ & - & $0.065^{* *}$ & $0.071^{* * *}$ \\
\hline$(-2)$ & - & - & $0.040^{* *}$ & - & - & $0.063^{* * *}$ \\
\hline$M U$ & 0.020 & 0.022 & 0.023 & -0.038 & -0.037 & -0.037 \\
\hline$(-1)$ & - & 0.034 & 0.034 & - & 0.018 & 0.018 \\
\hline$(-2)$ & - & - & -0.009 & - & - & 0.001 \\
\hline WTO & $0.169 * *$ & $0.177^{* *}$ & $0.176^{* *}$ & $0.043^{* *}$ & $0.049 * *$ & $0.049 * *$ \\
\hline$(-1)$ & - & -0.008 & -0.006 & - & 0.032 & 0.032 \\
\hline$(-2)$ & - & - & 0.007 & - & - & -0.002 \\
\hline EFTA & 0.048 & 0.040 & 0.034 & -0.007 & -0.006 & -0.003 \\
\hline$(-1)$ & - & $0.063^{* *}$ & $0.066^{* *}$ & - & 0.055 & 0.055 \\
\hline$(-2)$ & - & - & $0.036^{*}$ & - & - & -0.025 \\
\hline $\mathbf{n}$ & 492 & 478 & 464 & 492 & 478 & 464 \\
\hline Adj. $R^{2}$ & 0.4417 & 0.4518 & 0.4506 & 0.2782 & 0.2838 & 0.2780 \\
\hline$p$-value of DWH test & 0.1331 & 0.0974 & 0.1185 & 0.2673 & 0.2005 & 0.2217 \\
\hline
\end{tabular}

Note: Robust (HAC) standard errors are used. All regressions include time dummies. ${ }^{*}$ indicates significance at the $10 \%$ level; ${ }^{* *}$ indicates significance at the $5 \%$ level; ${ }^{* * *}$ indicates significance at the $1 \%$ level.

Source: Authors' calculations.

The key tenants of the EU's economic policy often have a defining effect on both the trade policy and trade volumes of the member states. The Treaty of the European Union contains the key aspects of this policy, especially article 207 where the EU institutions are obligated to observe the guiding principles of dealing with non-member/external entities. Specific areas in services trade are highlighted where the EU Council's approval is required 
for such treaties. Naturally, such trade restrictive measures do not always have a positive effect on member state export growth and that was also revealed by Allaro (2012) and Mukherjee and Chanda (2017). The implementation of broad foreign trade principles is objectively related to the protection of economic interests and political realities. Within the EU, especially after the accession of economically less developed Central and Eastern European states, the weaknesses and vulnerabilities of some economic sectors have become more apparent.

Another important factor with unequal effect on the EU member state export growth relates to the EU's commercial policy principles that lie at the foundation of the EU's FTAs. This is the market size of trade partners covering investment opportunities, as well as an array of protectionist measures applicable to exports from the EU. Additionally, the EU's secure access to natural resources (energy, rare metals, etc.) together with political requirements (adherence to human rights and principles of democratic government) play an important role in negotiating FTAs.

The results of our study indicate that the replacement of national currencies with euro has not had a significant impact on the dynamics of exports. This conclusion is in line with findings of Frankel (2008). A slight increase in exports to the Eurozone countries following the introduction of euro is attributable to existing long-term trade relations with them. A larger euro introduction effect on exports is discernible for smaller and lower-tech goods producing enterprises. Study confirmed that euro introduction has positively affected exports from traditionally export-oriented regions, yet has not substantially changed the situation in others.

\section{Conclusions}

The dynamics of export volumes of goods and services is viewed as one of the main determinants of economic development. Market-generated data relating to export volumes is of utmost importance for understanding the geographical and political situation of an exporting entity that affects the framework of long-term trade relations. From the perspective of importer (whether a country as a whole or a business entity) that is also interested in market entry as exporter, a more precise assessment of such prospects is enabled through analysis of exporter's competitive advantage and targeted optimal trade balance. However, the commercial and trade relations among various economic entities are truly complex in the current global trade environment. This complexity is further enhanced by factors, the stability and extent of which are not easily characterised or quantified. One of such factors identified in this article are global and regional organisations or institutions, membership of which has disparate effects on the opportunities for countries to increase their export volumes.

The results of our study indicate that joining Eurozone did not affect export growth. The impact of becoming a member of WTO occurs instantly but does not generate additional growth in longer period. On contrary, membership in the EU and EFTA seems to have an effect on export growth just with a time lag. In consistence with earlier researches on relationship between membership in various agreements and export growth it can be stated that results are contradictory. This was observed through a particularly large 
dispersion of export to the EU growth rates in the first year of the EU accession, regardless of the joining country's economic size. Among the largest accession states, the export growth of goods to the EU in the first accession year for the Czech Republic, Hungary, Slovakia and Poland amounted to $40.7 \%, 23.1 \%, 24.6 \%$ and $1.7 \%$, respectively. The positive effect of the EU accession on trade may have manifested itself through free movement of goods to other EU states, yet this effect could have been offset through insufficient readiness by acceding states to find exporting niches/markets in the EU.

In conclusion, we can state that analysis of membership impact on export growth has two main reasons: theoretical and empirical. The analyses of scientific research provided ambiguous results with respect to the relationship between membership and export growth. The empirical motivation refers to the lack of evidence. There is only limited scientific research offering econometric estimates of the membership on export growth using demand-side model which can be further extended including other export controls as well as those used in supply-side models.

\section{References}

Adis, A. A. (2010). Export Performance on the Malaysian Wooden Furniture Industry: An Empirical Study. Journal of International Food and Agribusiness Marketing, 22(1\&2), 52-69, http://doi.org/10.1080/08974430903372773

Adu-Gyamfi, N., Korneliussen, T. (2013). Antecedents of Export Performance: the Case of an Emerging Market. International Journal of Emerging Markets, 8(4), 354-372, https://doi.org/10.1108/IJoEM-Jun-2011-0056

Akdeve, E. (2013). The Determinants of Export Potential: A Case of Ankara Manufacturing Sector. International Journal of Business Management and Economic Research, 4(3), 745-751.

Allaro, H. B. (2012). The Impact of Trade Liberalization on the Ethiopia's Trade Balance. American Journal of Economics, 2(5), 75-81, https://doi/10.5923/j.economics.20120205.02

Alvarez, R. (2004). Sources of Export Success in Small and Medium-Sized Enterprises: the Impact of Public Programs. International Business Review, 13(3), 383-400, https://doi.org/10.1016/j.ibusrev.2004.01.002

Arellano, M. (2003). Panel Data Econometrics. Oxford: Oxford University Press. ISBN 9780199245291.

Balabanis, G. I., Katsikea, E. S. (2003). Being an Entrepreneurial Exporter: Does It Pay? International Business Review, 12(2), 233-252, https://doi.org/10.1016/s0969-5931(02) 00098-7

Baldauf, A., Cravens, D. W., Wagner, U. (2000). Examining Determinants of Export Performance in Small Open Economies. Journal of World Business, 35(1), 61-79, https://doi.org/10.1016/ S1090-9516(99)00034-6

Bouchoucha, M. (2015). The Euro Effect on Eurozone Exports. International Economic Journal, 29(3), 399-418, http://doi.org/10.1080/10168737.2015.1020324

Brouthers, L. E., Nakos, G. (2005). The Role of Systematic International Market Selection on Small Firms' Export Performance. Journal of Small Business Management, 43(4), 363-381, https://doi.org/10.1111/j.1540-627X.2005.00142.x 
Calabro, A., Mussolino, D. (2013). How do Boards of Directors Contribute to Family SME Export Intensity? The Role of Formal and Informal Governance Mechanisms. Journal of Management and Governance, 17(2), 363-403, https://doi.org/10.1007/ s10997-011-9180-7

Carneiro, J., Rocha, A. D., Silva, J. F. D. (2011). Determinants of Export Performance: A Study of Large Brazilian Manufacturing Firms. Brazilian Administration Review, 8(2), 107-132, http://doi.org/10.1590/S1807-76922011000200002

Carole M. (2009). Determinants of Export Performance in French Wine SMEs. International Journal of Wine Business Research, 21(2), 118-142, https://doi. org/10.1108/17511060910967971

Carrere, C. (2006). Revisiting the Effects of Regional Trade Agreements on Trade Flows with Proper Specification of the Gravity Model. European Economic Review, 50(2), 223-247, https://doi.org/10.1016/j.euroecorev.2004.06.001

D'Angelo, A. (2012). Innovation and Export Performance: A Study of Italian High-Tech SMEs. Journal of Management and Governance, 16(3), 393-423, https://doi.org/10.1007/ s10997-010-9157-y

Davidson, R., MacKinnon, J. G. (1993). Estimation and Inference in Econometrics. New York: Oxford University Press. ISBN 9780195060119.

Dell'Ariccia, G. (1999). Exchange Rate Fluctuations and Trade Flows: Evidence from the European Union. IMF Staff Papers, 46(3), 315-334, https://doi.org/10.2307/3867646

Eusebio, R., Andreu, J. L., Belbeze, M. P. L. (2007). Management Perception and Marketing Strategy in Export Performance. Journal of Fashion Marketing and Management, 11(1), 24-40, http://doi.org/10.4337/9781781954393.00021

Moghaddam, F. M., Bakar, A., Abdul, B., Zaleha, S., Rasid, A., Darestani, H. (2010). The Influence of Export Marketing Strategy Determinants on Firm Export Performance: A Review of Empirical Literatures between 1993-2010. IJFPSS, 1(2), 26-34.

Francois, J., Van Meijl, H., Van Tongeren, F. (2005). Trade Liberalization in the Doha Development Round. Economic Policy, 20(42), 350-391, https://doi.org/10.1111/ j.1468-0327.2005.00141.x

Frankel, J. (2008). The Estimated Effects of the Euro on Trade: Why Are They Below Historical Effects of Monetary Unions Among Smaller Countries? Harvard Kennedy School. Research Working Papers No. 08-076, https://doi.org/10.2139/ssrn.1314434

Gao, G. Y., Murray, J. Y., Kotabe, M., Lu, J. (2009). A Strategy Tripod Perspective on Export Behaviour: Evidence from Domestic and Foreign Firms Based in An Emerging Economy. Journal of International Business Studies, 41(3), 377-396, https://doi.org/10.1057/ jibs.2009.27

Gaur, J., Gupta, R. (2011). Comparing Firm Performance on the Basis of Age, Size, Leverage, and Group Affiliation in Indian IT Industry. Romanian Journal of Marketing, 6(3), 8-13.

Guner, B., Lee, J., Lucius, H. W. (2010). The Impact of Industry Characteristics on Export Performance: A Three Country Study. International Journal of Business and Economics Perspectives, 5(2), 126-141.

Heckscher, E. F., Ohlin, B. G. (1991). Heckscher-Ohlin Trade Theory. Cambridge, MA:The MIT Press. ISBN 0262082012.

Hultman, M., Katsikeas, C. S., Robson, M. J. (2011). Export Promotion Strategy and Performance: The Role of International Experience. Journal of International Marketing, 19(4), 17-39, https://doi.org/10.1509/jim.11.0022 
IMF (2003). Exchange Arrangements and Foreign Exchange Markets - Developments and Issues. Washington, United States: International Monetary Fund. ISBN 9781589061774, http://doi.org/10.5089/9781589061774.083

lyer, K. (2010). The Determinants of Firm-Level Export Intensity in New Zealand Agriculture and Forestry. Economic Analysis \& Policy, 40(1), 75-86.

Ju, J., Y. Wu, Zeng, L. (2010). The Impact of Trade Liberalization on the Trade Balance in Developing Countries. IMF Staff Papers, 57(2), 427-449, http://doi.org/10.1057/ imfsp.2009.19

Kassim, L. (2015). The Impact of Trade Liberalization on Export Growth and Import Growth in Sub-Saharan Africa. Regional Integration and Trade in Africa, 47-68, http://doi. org/10.1057/9781137462053_4

Katsikeas, C. S., Leonidas, C. L., Coudounaris, D. N. (2010). Five Decades of Business Research into Exporting: A Bibliographic Analysis. Journal of International Management, 16(1), 78-91, http://doi.org/10.1016/j.intman.2009.06.001

Lages, L. F., Montgomery, D. B. (2005). The Relationship between Export Assistance and Performance Improvement in Portuguese Export Ventures: an Empirical Test of the Mediating Role of Pricing Strategy Adaptation. European Journal of Marketing, 39(7-8), 755-784, https://doi.org/10.1108/03090560510601752

Lages, L. F., Silva, G., Styles, C. (2009). Relationship Capabilities, Quality, and Innovation as Determinants of Export Performance. Journal of International Marketing, 17(4), 47-70, https://doi.org/10.1509/jimk.17.4.47

Lee, C., Griffith, D. A. (2004). The Marketing Strategy-Performance Relationship in an Export Driven Developing Economy: a Korean Illustration. International Marketing Review, 21(3), 321-334, https://doi.org/10.1108/02651330410539648

Maurel, C. (2009). Determinants of Export Performance in French Wine SMEs. International Journal of Wine Business Research, 21(2), 118-142, https://doi. org/10.1108/17511060910967971

Mavrogiannis, M., Bourlakis M. A., Dawson P. J., Ness, M. R. (2008). Assessing Export Performance in the Greek Food and Beverage Industry. British Food Journal, 110(7), 638-654, https://doi.org/10.1108/00070700810887130

Mukherjee, S., Chanda, R. (2017). Differential Effects of Trade Openness on Indian Manufacturing Firms. Economic Modelling, 61, 273-292, https://doi.org/10.1016/j. econmod.2016.10.001

Mulligan, R. F. (1996). Export-Import Endogeneity in the Context of the Thirlwall Hussain Model: An Application of the Durbin-Wu-Hausman Test Incorporating a Monte Carlo Experiment. Applied Economics Letters, 3(4), 275-279, http://doi.org/10.1080/758520879

Murphy, G., Siedschlaga, I. (2011). Has the Euro Boosted Intra-Euro Area Exports? Evidence from Industry Data. Review of Economics and Institutions, 2(3), https://doi.org/10.5202/ rei.v2i3.44

O'Cass, A., Julian, C. (2003). Examining Firm and Environmental Influences on Export Marketing Mix Strategy and Export Performance of Australian Exporters. European Journal of Marketing, 37(3-4), 366-384, https://doi.org/10.1108/03090560310459005

Ottaviano, G., Martincus, C. V. (2011). SMEs in Argentina: Who Are the Exporters? Journal of Small Business Economics, 37(3), 341-361, https://doi:10.1007/s11187-009-9244-0 
Ratnaike, Y. C. (2012). Is There an Empirical between Trade Liberalisation and Export Performance. Economic Letters, 117(1), 375-378, https://doi.org/10.1016/j. econlet.2012.05.015

Reis, J., Forte, R. (2014). The Impact of Industry Characteristics on Firms' Export Intensity. International Area Studies Review, 19(3), 266-281, https://doi. org/10.1177/2233865916646560

Ricardo, D. (1955). The Works and Correspondence of David Ricardo. Volume 10, Biographical Miscellany. Cambridge University Press.

Rose, A. K. (2000). One Money, One Market: The Effect of Common Currencies on Trade. Economic Policy, 15(30), 8-45, https://doi.org/10.1111/1468-0327.00056

Rose, A. K., van Wincoop, E. (2001). National Money as a Barrier to International Trade: The Real Case for Currency Union. American Economic Review, 91(2), 386-390, https://doi.org/10.1257/aer.91.2.386

Samuelson, P. A. (1975). Trade Pattern Reversals in Time-Phased Ricardian Systems and Intertemporal Efficiency. Journal of International Economics, 5(4), 309-363, https://doi.org/10.1016/0022-1996(75)90037-9

Santos-Paulinio, A. U. (2007). Aid and Sustainability under Liberalisation in Least Developing Countries. The World Economy, 30(6), 972-998, https://doi. org/10.1111/j.1467-9701.2007.01040.x

Shujiro, U. (2002). Globalization and the Growth in Free Trade Agreements. Asia-Pacific Review, 9(1), 20-32, http://doi.org/10.1080/13439000220141569

Singh, D. A. (2009). Export Performance of Emerging Market Firms. International Business Review, 18(4), 321-330, https://doi.org/10.1016/j.ibusrev.2009.03.002

Sousa, C. M. P, Martínez-López, F. J., Coelho, F. (2008). The Determinants of Export Performance: A Review of the Research in the Literature between 1998 and 2005. International Journal of Management Reviews, 10(4), 343-374, https://doi.org/ 10.1111/j.1468-2370.2008.00232.x

Stoian, M. C., Rialp, A., Rialp, J. (2011). Export Performance under the Microscope: A Glance through Spanish Lenses. International Business Review, 20(2), 117-135, https://doi.org/10.1016/j.ibusrev.2010.07.002

Tantong, P., Karande, K., Nair, A., Singhapakdi, A. (2010). The Effect of Product Adaptation and Market Orientation on Export Performance: A Survey of Thai Managers. Journal of Marketing Theory and Practice, 18(2), 155-170, https://doi.org/10.2753/ mtp1069-6679180204

Vanek, J., Bertrand, T. (1971). Trade and Factor Prices in a Multi-Commodity World. Trade, Balance of Payments and Growth. Papers in International Economics in Honor of Charles P. Kindleberger. New York: Elsevier.

Williams, D. A. (2012). Industry Sector and Export Performance of Small, Locally-Owned Firms. Journal of International Business Research, 11(1), 15-27.

Winters, L. A. (2004). Trade Liberalisation and Economic Performance: an Overview. The Economic Journal, 114(493), F4-F21, https://doi.org/10.1111/j.0013-0133.2004.00185.x

Zakaria, M. (2014). Effects of Trade Liberalization on Exports, Imports and Trade Balance in Pakistan: A Time Series Analysis. Prague Economic Papers, 23(1), 121-139, https://doi.org/10.18267/j.pep.476 